\title{
CORPORATE SOCIAL RESPONSIBILITY AS A MODERATOR IN THE EFFECT OF SEL-EFFICACY ON ENTREPRENEURIAL MOTIVATION
}

\author{
Siswanti Yuni ${ }^{*}$ \\ Management Department, Faculty of Economics and Business, \\ UPN "Veteran" Yogyakarta, Indonesia \\ Muhsin Ahmad \\ Faculty of Industrial Engineering, UPN “Veteran" Yogyakarta, Indonesia \\ ORCID: 0000-0003-2457-268x \\ Nurhadi Djono \\ Department of Management, Faculty of Economics and Business, \\ UPN "Veteran" Yogyakarta, Indonesia \\ *E-mail: yuni.siswanti@upnyk.ac.id
}

\begin{abstract}
Responsibility of an organization for the impacts of its decisions and activities on society and the environment, through transparent and ethical behavior that contributes to sustainable development, health and the welfare of society; takes into account the expectations of stakeholders; is in compliance with applicable law and consistent with international norms of behavior; and is integrated throughout the organization and practiced in its relationships. The name of this is Corporate Social Responsibility (CSR). The purpose of this study was to examine the effect of self-efficacy on entrepreneurial motivation $\left(\mathrm{H}_{1}\right)$, THE effect of Corporate Social Responsibility (CSR) to moderate the impact self-efficacy on Entrepreneurial motivation $\left(\mathrm{H}_{2}\right)$. Based on research results, it can be concluded that self-efficacy was a positive and significant impact to entrepreneurial motivation $\left(\mathrm{H}_{1}\right.$ was supported), Corporate Social Responsibility (CSR) was not moderated the impact self-efficacy to entrepreneurial motivation $\left(\mathrm{H}_{2}\right.$ was not supported).
\end{abstract}

\section{KEY WORDS}

Self-efficacy, entrepreneurial motivation, corporate social responsibility, public relations.

The growth of employment in Indonesia with the growth of job seekers is no longer balanced. This has the potential to increase poverty in the community, including in rural areas. One way to overcome labor problems, improve Indonesia's economic growth, and reduce poverty is to give birth to new entrepreneurs. In line with this statement, Robbins (2016) states that the factors driving rapid economic growth are human factors, by carrying out productive activities, then it will bring up economic growth. Economic growth can be started from a narrow scope namely rural. Most rural people still live on economic incomes that are less than the standard, resulting in the fulfillment of their primary needs. This condition is often categorized as poor. One step against poverty is to empower women so that they become individuals who can earn their own income and at the same time help meet family needs. Empowerment can be done through the Corporate Social Responsibility (CSR) program. This research aims to find out the effect of self-efficacy on entrepreneurial motivation and the role of Corporate Social Responsibilities (CSR) in moderating the effect of self-efficacy on the entrepreneurial motivation of PKK women in Tegaltirto Village.

\section{LITERATURE REVIEW}

Self-efficacy refers to an individual's belief in his or her capacity to execute behaviors necessary to produce specific performance attainments (Bandura, 1977, 1986, 1997). Self- 
efficacy reflects confidence in the ability to exert control over one's motivation, behavior, and social environment. Luthan (2014) states that self-efficacy refers to self-confidence regarding its ability to motivate cognitive resources and the actions needed to succeed in carrying out certain tasks. According to Alwisol (2014) states that self-efficacy is an assessment of whether a person can do good or bad actions, right or wrong, can or cannot do something with the conditions given. Kreitner and Kinicki (2014) self-efficacy is one's belief about the chance of success in completing a particular job. Based on this description it can be concluded that the definition of self-efficacy is one's self-confidence in himself that he is able to complete his work. High self-efficacy can make it easier for individuals to measure their abilities, namely, with the confidence they have, they feel confident and able to complete their work or if they get a new challenge will be able to carry it out.

According to Bandura (1998), the perception of self-efficacy in each individual develops from the gradual achievement of certain abilities and experiences. The ability to perceive cognitively of the capabilities possessed gives rise to confidence or self-stability which will be used as a foundation for individuals to try as much as possible to achieve the targets set.

According to Bandura (1998), self-efficacy can be grown and studied through four main sources of information. The following are the aspects that affect self-efficacy:

1) Mastery experience. The experience of success will increase individual self-efficacy, while the experience of failure will decrease it. After strong self-efficacy develops through a series of successes, the negative impact of common failures will be reduced. It can strengthen self-motivation if one discovers through experience that even the most difficult obstacles can be overcome through constant effort.

2) The experience of others (vicarious experience). Observation of the success of others with comparable abilities in doing a task will increase individual self-efficacy

3) Verbal persuasion (verbal persuasion). In verbal persuasion, individuals are directed with advice, advice, and guidance, to increase their beliefs about their abilities that can help achieve the desired goals. Individuals who are verbally convinced tend to try harder to achieve success.

4) Physiological conditions. Physical tension in stressful situations is seen by individuals as a sign of incompetence because it can weaken individual work performance.

The following are three indicators of Self Efficacy (Bandura, 1986):

1) Dimension level (magnitude / level). This dimension is related to the degree of difficulty of the task when individuals feel able to do it. This dimension has implications for the choice of behavior to be tried or avoided. Individuals will try to behave in ways they feel capable of doing and avoid behaviors that are beyond their perceived ability.

2) Dimension of strength. This dimension relates to the level of strength of an individual's beliefs or expectations regarding his abilities. Solid hope drives individuals to persevere in their business. Although it may be found an experience that is not supportive. This dimension is usually directly related to the level dimension (magnitude), i.e. the higher the level of difficulty of the task, the weaker the perceived confidence to complete it.

3) Dimensions of generalization (generality). This dimension relates to the broad field of behavior in which individuals feel confident about their abilities. Individuals can feel confident about their abilities. Is it limited to a certain activity and situation or a series of varied activities and situations?

Entrepreneurship as a much broader concept than the creation of a new business venture. One of the concepts of entrepreneurship is creativity and innovation. It is concerned with innovation in the view of opportunities and risks, new approaches to problem-solving, having a strategic plan to recognize opportunities and risks, and minimizing the risks that can occur. Planning and creating a strategy is one of the important parts of the entrepreneurship concept as well, and it supports generating business success. The major factor in entrepreneurship is the role of the entrepreneur who takes thorough responsibility for the operation of the business. (Nadire Yimamu, 2018).

Motivation is the set of energetic forces that originate within as well as beyond individuals to initiate behavior and determine its form, direction, intensity, and duration (Mitchell \& Daniels, 2003 ) has been a core topic in psychological science and organizational 
behavior (OB) for over a century (Kanfer, Frese, \& Johnson, 2017). During this time, several subdomains within the literature have emerged based on specific theories of motivation and upon how motivation operates in specific contexts. One particularly active subdomain focuses on understanding what motivates entrepreneurs to start, grow, and exit their ventures.

The entrepreneurial motivation is the process that activates and motivates the entrepreneur to exert a higher level of efforts for the achievement of his/her entrepreneurial goals. In other words, entrepreneurial motivation refers to the forces or drive within an entrepreneur that affects the direction, intensity, and persistence of his / her voluntary behavior as an entrepreneur. So to say, a motivational entrepreneur will be willing to exert a particular level of effort (intensity), for a certain period (persistence) toward a particular goal (direction). People have different motivations, ability, and desire to grab the opportunity they see and become entrepreneurs. According to their different motivations, they have a different perception of opportunity considerations, risk-taking behavior and decision-making process (Shane \& Locke \& Collins 2000.) Behind every successful entrepreneur there are some questions that make people curious all the time, where do the persistent motivations come from and help them achieve their goals. Broadly speaking there are two major motivational factors, internal and external motivation factors. Such as a need for achievement, need for independence, need for financial freedom, and persistent love for doing something great as pull factors in entrepreneurship (Nel, Maritz \& Thongprovati, 2010).

This is in line with the theory put forward by Conger (1997) saying motivation is the drive to act to satisfy a need. Motivation is a causal variable that is used to cause behavioral factors and carry out behavior towards the target. Motivation has the function to run, encourage and move a person or group to do something. This statement is supported by Robbin (2016), who states that motivation as a process that also determines the intensity, direction, and perseverance of individuals to achieve goals.

The term entrepreneur is derived from the entrepreneur (French) which is translated into English with the meaning between taker or go-between. There are developments in the theory and definition of entrepreneurship whose origin is said to be a translation from entrepreneurs. The development of the theory and term entrepreneur in the middle ages meant that the actor or person responsible for large-scale production. According to As ad (2003), an entrepreneur is someone who has the ability and attitude to be independent, creative, innovative, resilient, far-sighted, taking moderate risks and without ignoring others in their fields or society. According to Schumpeter (2010) what is called an entrepreneur is someone who breaks down the existing economic system and moves the people's economy forward. Entrepreneurs are individuals, who dare to take risks, coordinate, manage investment or production facilities and introduce the function of new production factors or who can respond creatively and innovatively.

Entrepreneurial motivation can be explained by expressing three motivational aspects of Conger (1997) combined with entrepreneurial characteristics put forward by Scarborrough and Zimmerrer (2004) which are judged to be superior in theory to reveal aspects of entrepreneurial motivation in this study, namely: having a positive nature, oriented toward achieving a goal, and the forces that drive individuals. According to Alma (2010) states that several factors play a role in opening a new business, namely personal, sociological, environmental, and other factors (work experience, energy, optimism). Sujatmoko \& Karyono (2013) states that the higher individual self-efficacy, therefore, motivation within entrepreneurship will higher too, thus also on the contrary. The self-efficacy variable was given an effective contribution of about $50,4 \%$ whereas the other about $49,6 \%$ was influenced by another factor that wasn't discussed in this research.

Bowen (1953) defines that CSR is made decisions according to the values of our society. Trapp (2012) sees CSR as the moment in which corporations reflect their concerns about social and global issues on their activities, even when some of those concerns might not be directly linked to their core business. Carrol (2015) is the concepts of stakeholder engagement and management, business ethics, corporate citizenship, corporate sustainability, and the creation of shared value are all interrelated and overlapping and all of 
them have been incorporated into CSR. Carrol (2015) defines CSR as the benchmark and central piece for the socially responsible movement. CSR could be defined as the voluntary commitment of companies to contribute to sustainable economic development by integrating social and environmental concerns into their operations and interactions (Banerjee, 2008).

Many researchers agree that entrepreneurs have contributed significantly to the world's society, the economy as well as humankind through job creation, utilization of business opportunities and product innovation (Majid \& Koe, 2012).

Shaheen \& AL-Haddad (2018) find that entrepreneurial self-efficacy has an influence on entrepreneurial behavior. According to Bandura (1977), self-efficacy in an activity such as entrepreneurship develops through the following four processes: I) performance accomplishments, II) vicarious experience, III) verbal persuasion and IV) physiological states or physiological arousal, thus through entrepreneurship education programs, these four processes can be enhanced and thus self-efficacy can be enhanced which is expected to lead to entrepreneurial behavior, furthermore there is enough theoretical basis to prove that educational interventions in the field of entrepreneurship may increase entrepreneurial behavior (Rideout and Gray, 2013).

Hypothesis 1: Self Efficacy has a positive effect on entrepreneurial motivation; by CSR.

Hypothesis 2: The effect of self-efficacy on entrepreneurial motivation is moderated

\section{METHODS OF RESEARCH}

The research method used is descriptive and explanatory survey(census method). The respondents must have a business (self or team) from 39 entrepreneurs. All of them is a woman in Tegaltirto village, Berbah, Sleman, Yogyakarta that joined together in PKK. PKK is a program at the village level to educate women on various aspects of family welfare. They produced some of the handicrafts, snacks, and ginger drinks. Data collection techniques among other things by distributing a questionnaire (questionnaire), limited interviews, and observation. Data collection tool in the form of the questionnaire. Validity and reliability testing used to test instruments, and all of the instruments were valid and reliable. Analysis hypothesis using regression analysis and hierarchical regression analysis. The research team used a structured and unstructured interview and questionnaire.

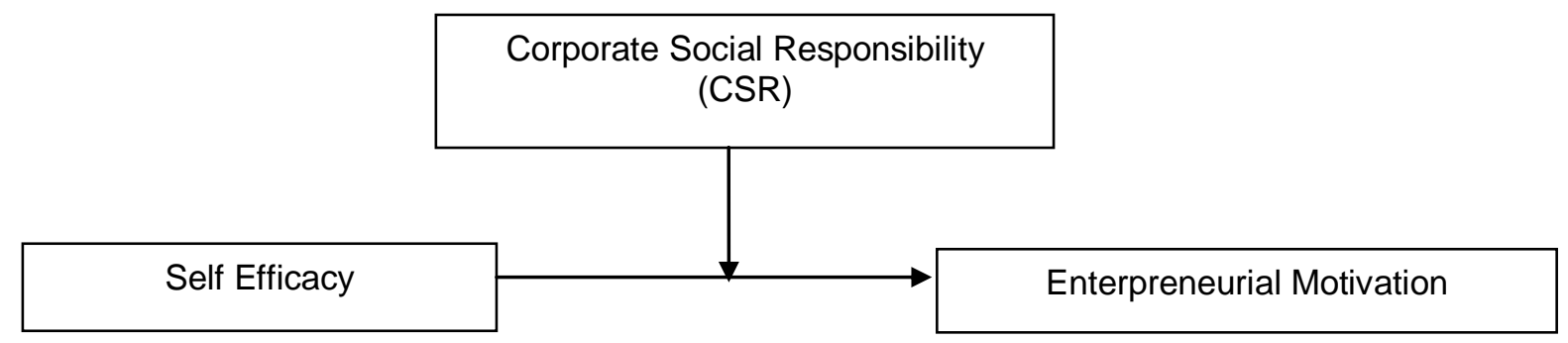

Figure 1 - Research Model

We used a formative structure to measure entrepreneurial motivation (MacKenzie et al, 2005). Six items gathered from the studies Chelariu et al. (2008) and Lee et al. (2011) captured the relevant dimensions, with scales ranging from "strongly disagree" to "strongly agree". General self-efficacy was measured with an eight-item scale developed by Chenet (2001). The instrument of CSR used from 17 items Gonzalesh et al (2019). To strengthen the research result and make it easier to be understood, the research team also did documentation with photos and other resources. The research team also conducted data cross-check in the field with reliable sources and related references. They also consulted with experts in the validity and reliability test (Muafi \& Wijayani, 2015; Kostrad et al, 2018).

From the partial regression test, it is known that Self-efficacy influences positively and significantly on entrepreneurial motivation (Hypothesis 1 supported). 
Table 1 - Classification of respondents by gender, age, and educational qualification

\begin{tabular}{|c|c|c|c|}
\hline \multirow{3}{*}{ Age } & $18-34$ & 15 & $38,5 \%$ \\
& $35-54$ & 17 & $43,6 \%$ \\
\hline \multirow{3}{*}{ Business Unit } & 54 -above & 7 & $17,9 \%$ \\
\hline \multirow{3}{*}{ Village } & Handicrafts & 7 & $17,9 \%$ \\
& Snacks & 12 & $30,8 \%$ \\
& Ginger Drinks & 20 & $51,3 \%$ \\
\hline & Krikilan & 3 & $7,7 \%$ \\
& Kadisono - Sonosari & $3,7 \%$ \\
& Berbah-Sanggrahan & 2 & $7,1 \%$ \\
& Dondong & 3 & $7,7 \%$ \\
& Candirejo & 3 & $5,1 \%$ \\
& Jagalan & 2 & $7,7 \%$ \\
& Karangwetan & 3 & $7,7 \%$ \\
& Kunden & 3 & $7,7 \%$ \\
& Kuton & 3 & $7,7 \%$ \\
& Pendem & 3 & $7,7 \%$ \\
& Semoyo & 3 & $7,7 \%$ \\
\hline
\end{tabular}

Source: Survey, 2019.

Table 2 - Effect of Self Efficacy to Entrepreneurial Motivation

Coefficients(a)

\begin{tabular}{|c|c|c|c|c|c|c|}
\hline \multirow{2}{*}{ Model } & & \multicolumn{2}{|c|}{ Unstandardized Coefficients } & Standardized Coefficients & t & Sig. \\
\cline { 3 - 7 } & & B & Std. Error & Beta & B & Std. Error \\
\hline \multirow{2}{*}{1} & (Constant) & $-2,207$ & 1,852 & & $-1,192$ &, 241 \\
\cline { 2 - 7 } & Self Efficacy $(X)$ & 1,652 &, 447 &, 519 & 3,694 &, 001 \\
\hline
\end{tabular}

(a) Dependent Variable: Entrepreneurial Motivation (Y).

Source: Regression Test, 2019.

Table 3 - Hasil Uji H2 Moderation Effect

Coefficients(a)

\begin{tabular}{|c|c|c|c|c|c|c|}
\hline \multirow{2}{*}{ Model } & & \multicolumn{2}{|c|}{ Unstandardized Coefficients } & Standardized Coefficients & $\mathrm{t}$ & Sig. \\
\cline { 3 - 7 } & & $\mathrm{B}$ & Std. Error & Beta & $\mathrm{B}$ & Std. Error \\
\hline \multirow{2}{*}{1} & (Constant) & $-2,207$ & 1,852 & & $-1,192$ &, 241 \\
\cline { 2 - 7 } & Self Efficacy $(\mathrm{X})$ & 1,652 &, 447 &, 519 & 3,694 &, 001 \\
\hline \multirow{3}{*}{2} & (Constant) & $-1,729$ & 1,868 & &,- 926 &, 361 \\
\cline { 2 - 7 } & Self Efficacy $(\mathrm{X})$ & 1,320 &, 508 &, 415 & 2,601 &, 013 \\
\cline { 2 - 7 } & Moderasi &, 051 &, 038 &, 213 & 1,333 &, 191 \\
\hline
\end{tabular}

(a) Dependent Variable: Entrepreneurial Motivation (Y).

Source: Moderating Regression, 2019.

H2 test results show that CSR does not moderate the effect of Self Efficacy on Entrepreneurial Motivation (H2 was not supported).

\section{DISCUSSION OF RESULTS}

Test of hypothesis 1 results that self-efficacy has a positive and significant effect on entrepreneurial motivation. That is when an individual's self-efficacy increases it will increase his motivation for entrepreneurship. The results of this research support previous research: Shaheen \& AL-Haddad (2018) find that entrepreneurial self-efficacy has an influence on entrepreneurial behavior.

According to Bandura (1977), self-efficacy in an activity such as entrepreneurship develops through the following four processes: I) performance accomplishments, II) vicarious experience, III) verbal persuasion and IV) physiological states or physiological arousal, thus through entrepreneurship education programs, these four processes can be enhanced and thus self-efficacy can be enhanced which is expected to lead to entrepreneurial behavior, 
furthermore there is enough theoretical basis to prove that educational interventions in the field of entrepreneurship may increase entrepreneurial behavior (Rideout and Gray, 2013)

This research was supported by Sujatmoko \& Karyono (2014) that the higher individual self-efficacy because motivation within entrepreneurship would be higher too, thus also on the contrary. If women in rural areas have high self-efficacy, it will potentially increase their motivation for entrepreneurship. With high motivation for entrepreneurship, it is expected to generate their own income, help meet the needs of the family's economy, as well as the macro impact on reducing poverty levels.

Test of Hypothesis 2 results indicate that CSR does not moderate the effect of selfefficacy on entrepreneurial motivation. That is, the presence or absence of CSR, from any party, does not necessarily affect the effect of self-efficacy on the entrepreneurial motivation of mothers in Tegaltirto Village, Berbah, Sleman, Yogyakarta. The results of this research do not support previous research that entrepreneurs have contributed significantly to the world's society, the economy as well as humankind through job creation, utilization of business opportunities and product innovation (Majid \& Koe, 2012). Not supported this second hypothesis becomes a good finding for the addition of academic insights because when a woman's self-efficacy in Tegaltirto Village will positively influence her motivation for entrepreneurship, and the existence of CSR from other parties does not necessarily increase her motivation for entrepreneurship. This is possible because women in rural areas are mostly aware that the growing need for life triggers them to empower themselves in their own way. One way that can be used as well as the real form is entrepreneurship. When the potential for entrepreneurship in rural areas develops well, it has a positive effect on meeting basic needs, and the subsequent impact on reducing poverty levels.

\section{CONCLUSION}

Hypothesis 1 test results which state that self-efficacy has a positive effect on entrepreneurial motivation are supported. Hypothesis 2 test results that state CSR moderates the effect of self-efficacy on entrepreneurial motivation not supported.

The object of this research is still narrow because it is only a rural area. Further research should develop to the sub-district, district or province-level so that the results can be generalized. Further research can also be conducted on employees who work in government agencies or the private sector because the results may be very different from the results of current research.

Data retrieval is cross-sectional, so it cannot be used as a basis for long-term decision making. Further research should try the time series method (eg, taking data back to the same respondent in the next 6 months or 1 year).

Further research needs to be done on the existence of other moderating variables included in the interaction of self-efficacy on entrepreneurial motivation, such as family support, leadership, work environment, and so on.

\section{REFERENCES}

1. Alma, Buchari (2010). Kewirausahaan Untuk Mahasiswa dan Umum. Bandung: Alfabeta

2. As'ad, M. 2003. Psikologi Industri: Seri Sumber Daya Manusia: Liberty. Yogyakarta.

3. Bandura, A. (1977), "Self-efficacy: toward a unifying theory of behavioral change", Psychological Review, Vol. 84 No. 2, pp. 191-215.

4. Bandura, A. (1986), "From thought to action: mechanisms of personal agency", New Zealand. Journal of Psychology, Vol. 15 No. 1, pp. 1-17.

5. Bandura, A. (1997), Self-efficacy: The Exercise of Control, W.H. Freeman, New York, NY.Bandura, A. (2012), "On the functional properties of perceived self-efficacy revisited", Journal of Management, Vol. 38 No. 1, pp. 9-44.

6. Bandura, A. (1997). Social Learning Theory. New Jersey: Englewood Cliffs Prentice Hall.

7. Banerjee, S. B. (2008). Corporate Social Responsibility: The Good, the Bad and the Ugly. Critical Sociology. 34(1), 51-79. 
8. Bowen, H. R. (1953).Social responsibilities of the businessman. University of lowa Press.

9. Carroll, A. B. (2015). Corporate social responsibility: The centerpiece of competing

10. and complementary frameworks. Organizational Dynamics, 44(2), 87-96.

11. Chen, G, Gully, S.M, and Eden, D. (2001), "Validation of a new general self-efficacy scale", Organizational Research Methods, Vol. 4 No. 1, pp. 62-83.

12. Chelariu, C, Brashear, T.G, Osmonbekov, T. and Zait, A.(2008), "Entrepreneurial propensity in a transition economy: exploring micro-level and meso-level cultural antecedents", Journal of Business \& Industrial Marketing, Vol. 23 No. 6, pp. 405-415

13. Conger, J. A, Kanungo, R. N, Menon, S. T, \& Mathur, P. (1997). Measuring Charisma: Dimensionality and Validity of the Conger-Kanungo Scale of Charismatic Leadership. Canadian Journal of Administrative Sciences/Revue Canadienne des Sciences de l'Administration, 14, 290-301. http://dx.doi.org/10.1111/j.1936-4490.1997.tb00136.x

14. Diharto, Awan.K, Muafi, Resmi. S, Siswanti, Yuni, Retnaningdyah, D, Ghofar. A, \& Kusumawati, R.a. 2018. THE role of women empowerment and organizational agility toward the resilience of disaster-affected batik small medium enterprises: an effort to overcome technology disruptive. International Journal of Mechanical Engineering and Technology (IJMET). Volume 9, Issue 4, April 2018, pp. 136-144.

15. Gonzaleza, Bande, Ferrín, Kimura. 2019. Data to model the influence of CSR on consumer behaviors: A process approach. Data in brief 27. https://doi.org/10.1016/j.dib.2019.104713.

16. Haddad, S. and Taleb, R. (2016), "The impact of self-efficacy on performance (An empirical study on business faculty members in Jordanian universities)", Computers in Human Behavior, Vol. 55, pp. 877-887.

17. Lee, L, Wong, P.K, Der Foo, M. and Leung, A. (2011), "Entrepreneurial intentions: the influence of organizational and individual factors", Journal of Business Venturing, Vol.26No. 1, pp. 124-136.

18. MacKenzie, S.B, Podsakoff, P.M. and Jarvis, C.B. (2005), "The problem of measurement model misspecification in behavioral and organizational research and some recommended solutions", Journal of Applied Psychology, Vol. 90 No. 4, pp. 710-730.

19. Majid, I. A. \& Koe, W. (2012). Sustainable Entrepreneurship: A Revised Model Based on the Triple Bottom Line. International Journal of Academic Research in Business and Social Sciences. 2(6), 293-310.

20. Muafi, \& Wijayani, A. (2015). Redesign process of job analysis and job satisfaction: a qualitative study on the combined group on the farmer (GAPOKTAN), Jurnal Dinamika Manajemen, 6 (2) 2015, 197-206.

21. Nadire Yimamu. 2018. Entrepreneurship and Entrepreneurial Motivation. Centria University of Applied Sciences.

22. Nel, P, Maritz, A. \& Thongprovati, O. 2010.Motherhood and entrepreneurship: The mumpreneur phenomenon. International Journal of Organizational Innovation, 3(1):6-34.

23. Pearce, J, Kramer, T, and Robbins, D. (1997), "Effects of managers' entrepreneurial behavior on subordinates", Journal of Business Venturing, Vol. 12 No. 2, pp. 147-160.

24. Rideout, E. and Gary, D. (2013), "Does Entrepreneurship Education Really Work? A Review and Methodological Critique of the Empirical Literature on the Effects of University-Based Entrepreneurship Education", Journal of Small Business Management, Vol. 51 No. 3, pp. 329-351.

25. Shane, S, Locke, E. A. \& Collins, C. J. 2012. Entrepreneurial motivation. Human Resource Management Review, 13(2), 257-279.

26. Shaheen, Noor, \& AL-Haddad, Shafig. 2018. Entrepreneurial self-efficacy and entrepreneurial behavior. International Journal of Development and Sustainability. Volume 7 Number 10: Pages 2385-2402.

27. Sujatmoko, Mega.B, \& Karyono. 2013. Hubungan antara self efficacy dengan motivasi berwirausaha pada mahasiswa jurusan teknik Kimia Universitas Dipone3goro semarang. Vol. 2, No. 4. https://ejournal3.undip.ac.id/index.php/empati.

28. Trapp, N. L. (2012). Corporation as climate ambassador: Transcending business sector boundaries in a Swedish CSR campaign. Public Relations Review, 38(3), 458-465. 